\title{
CHARACTERIZATION OF FUSARIUM ISOLATES FROM RICE, SUGARCANE AND MAIZE USING RFLP-IGS
}

\author{
Heng Mei Hsuan, Latiffah Zakaria*, Baharuddin Salleh \\ School of Biological Sciences, Universiti Sains Malaysia, 11800 Minden, Pulau Pinang, Malaysia
}

Received: December 21, 2009

Accepted: July 29, 2010

\begin{abstract}
Isolates of Fusarium from rice, sugarcane and maize were identified as F. verticillioides, F. sacchari, F. proliferatum F. subglutinans, F. fujikuroi and F. oxysporum. The species were then characterized by restriction analysis of intergenic spacer (RFLP-IGS) using AluI, Eco88I, RsaI and XhoI. Twenty-five haplotypes were identified among the isolates of Fusarium which indicated high levels of variations. UPGMA cluster analysis was conducted to cluster the isolates and to estimate the intraspecific and interspecific variability. Isolates of $F$. fujikuroi from rice were clustered together with isolates of $F$. proliferatum from rice and maize with a similarity value of $88-100 \%$. Isolates of F. verticilliodes from maize and sugarcane were clustered together with a similarity value ranging from $92-100 \%$, and two isolates from rice formed another cluster. Isolates of F. oxysporum from maize and rice were clustered together with a similarity value ranging from $87-95 \%$. Isolates of F. subglutinans from rice and maize, and F. sacchari from rice and sugarcane were also clustered together with a similarity value of $77-100 \%$. Based on RFLP-IGS analysis, variability was observed within and between species of Fusarium from rice, maize and sugarcane and the technique could be use to complement morphological characterization and to determine genetic relationships between the species.
\end{abstract}

Key words: Fusarium, rice, sugar cane, maize, RFLP-IGS

\section{INTRODUCTION}

Rice (Oryza sativa), sugarcane (Saccharum sp.) and maize (Zea mays) are among the important agricultural crops in Malaysia. Rice is the staple food of Malaysians and mainly planted for domestic consumption. Sugarcane is cultivated on a small-scale. Cultivation of improved varieties have produced yields which have increased steadily. Sugarcane in Malaysia is often associated with the food processing industry which has increased over the years because the demand for sugar has increased. Maize is planted as a cash crop to generate extra income for farmers. It is planted on a small-scale.

Species of Fusarium are among the plant pathogenic fungi which commonly infected the three crops. The most common species of Fusarium associated with rice, sugarcane and maize were from the section Liseola although other species have also been reported on these crops (Leslie and Summerell 2006).

For identification of Fusarium species, morphological characteristics are often used, however it is sometimes difficult and requires considerable expertise. Therefore, molecular approaches such as: combination of PCR and restriction analysis (RFLP) are widely used in taxonomic studies of Fusarium. PCR-RFLP has often been used to analyze both the conserved and variable regions of rDNA. One of the variable regions is the intergenic spacer (IGS) which separate the repeated ribosomal units and appears to be the most rapidly evolving spacer region (Hillis and
Dixon 1991). Restriction analysis of IGS (RFLP-IGS) has been used to provide useful information on the intraspecific variation (Patino et al. 2006) and also to discriminate species of Fusarium at different taxonomic levels (Edel et al. 1995). Therefore, the present study was conducted to characterize isolates of Fusarium isolated from rice, sugarcane and maize using a morphological approach and RFLP-IGS analysis.

\section{MATERIALS AND METHODS}

Isolation of Fusarium isolates

Rice and maize samples were collected from Gurun, Kedah and sugarcane from Chuping, Perlis, in the northern Malay Peninsula. Isolation of Fusarium isolates from rice was made from roots showing bakanae symptoms. From maize, isolation was made from different parts of the plant showing disease symptoms; such as leaves with lesions, stunted flowers and infected kernels. Isolations from sugarcane were made from leaves with pokkah boeng symptoms of crumpled, stunted, twisted leaves and chlorosis near the base.

The diseased plant parts were cut to approximately $1 \mathrm{~cm}^{2}$ and the surface was sterilized using 10\% sodium hypochlorite for $1 \mathrm{~min}$. The plant parts were then transferred into sterile distilled water and soaked for $30 \mathrm{~s}$ and put onto Peptone PCNB Agar (PPA). The PPA plates were incubated at $25^{\circ} \mathrm{C}$ for 3 days. After mycelial growth was 
observed, the mycelia were transferred to potato dextrose agar (PDA). Flowers and kernels from maize were directly plated on PPA and incubated at $25^{\circ} \mathrm{C}$ until mycelial growth was observed from the samples. The mycelia were then transferred onto PDA and potato sucrose agar (PSA).

To obtain pure culture, single spore technique was conducted. Mycelia were scraped from 5-day-old colony and suspended in $10 \mathrm{ml}$ sterilized distilled water. A sterilized inoculation loop was used to take a small portion of the conidial suspension and streaked on water agar (WA). The inoculated plates were incubated at $25^{\circ} \mathrm{C}$ for 18 hours to allow the conidia to germinate. The single spore cultures were used for morphological characterization.

\section{Morphological characterization}

Species of Fusarium were identified by using the descriptions in The Fusarium Laboratory Manual (Leslie and Summerell 2006). Carnation Leaf Agar (CLA) was used to observe the morphological characteristics of Fusarium species. The morphological characteristics used for species identification were the shapes, sizes and formation of macroconidia and microconidia, formation of conidiophores and, presence or absence of chlamydospores. Pigmentation was observed using PDA.

\section{RFLP-IGS}

All the isolates successfully recovered from rice, maize, sugarcane, and 10 isolates from the Fusarium Culture Collection, School of Biological Sciences, Universiti Sains Malaysia were used in RFLP-IGS analysis (Table 1). The 10 isolates from the culture collection were also isolated from the three hosts and were morphologically identified.

For DNA extraction, mycelia were harvested from PDA plates after 7 days of incubation at $25^{\circ} \mathrm{C}$. The DNA was extracted using a DNeasy Plant Mini Kit (Qiagen, USA) according to the manufacturers' instructions. IGS region was amplified using primer pair described by Appel and Gordon (1995) i.e. CNL12 (CTGAACGCCTCTAAGTCAG) and CNS1 (GAGACAAGCATATGACTACTG). PCR amplification reactions were conducted in a $50 \mu$ reaction mixture containing $1 \mathrm{X}$ PCR buffer, $3.5 \mathrm{mM} \mathrm{MgCl}_{2}, 0.16 \mathrm{mM}$ of dNTP mix, 1.75 unit GoTaq DNA polymerase (Promega), $0.3 \mu \mathrm{M}$ of each primers and $0.35 \mu \mathrm{l}$ template DNA up to a total volume of $50 \mu \mathrm{l}$ with deionized distilled water. Twenty-five $\mu \mathrm{l}$ of paraffin oil was added to overlay each reaction.

PCR amplification was performed in DNA Engine ${ }^{\mathrm{TM}}$ Peltier Thermal Cycler Model PTC - 100 with an initial denaturation at $94^{\circ} \mathrm{C}$ for 2 min followed by 35 cycles of denaturation at $94^{\circ} \mathrm{C}$ for $35 \mathrm{~s}$, annealing at $59^{\circ} \mathrm{C}$ for $55 \mathrm{~s}$ and extension at $72^{\circ} \mathrm{C}$ for $2 \mathrm{~min}$, followed by final extension for $7 \mathrm{~min}$ at $72^{\circ} \mathrm{C}$. Negative controls were used to test for the presence of nonspecific reaction. The PCR product was detected in 1.5\% agarose (Promega) gel electrophoresis, run in TBE buffer at $100 \mathrm{~min}, 80 \mathrm{~V}$ and $400 \mathrm{~mA}$. The gel was stained with ethidium bromide and visualized under UV transalluminator. The size of the amplified IGS band was estimated by comparison to $1 \mathrm{~kb}$ marker (Fermentas).
Four restriction enzymes, AluI, RsaI, Eco88I and XhoI (Fermentas) were used to digest the PCR products in a total volume of $15 \mu \mathrm{l}$ reaction. The digestion procedure was according to the manufacturers' instructions. Digested PCR product was run in $2 \%$ agarose (Promega) gel in TBE buffer for $140 \mathrm{~min}$ at $80 \mathrm{~V}$ and $400 \mathrm{~mA}$, stained with ethidium bromide and visualized on a UV transalluminator. The size of the restriction fragments were estimated and analyzed by comparison to 100 bp DNA marker (Fermentas) with The Discovery Series ${ }^{\mathrm{TM}}$ Quantity One ${ }^{\circledR} 1-\mathrm{D}$ Analysis software version 4.6.5.

\section{Data Analysis}

Numerical Taxonomy and Multivariate Analysis System (NT-SYS) software package Version 2.0 (Rohlf 2000) was used to analyze the data. All reproducible restriction fragments were scored on the basis of absence (0) and presence (1) of particular bands. The binary data was then constructed to generate a similarity matrix using simple matching coefficient. Cluster analysis was performed using the Unweighted Pair-group Method with arithmetic Mean (UPGMA). Each of the isolates was also assigned to a composite haplotype which is defined by a combination of the restriction patterns obtained using the four restriction enzymes: AluI, RsaI, Eco88I and XhoI.

\section{RESULTS}

A total of 30 isolates of Fusarium were successfully isolated from samples collected from the field. Three species from rice were identified as F. proliferatum, F. oxysporum and F. sacchari. From maize, F. subglutinans, F. proliferatum, F. verticillioides and F. oxysporum were recovered from different parts of the plant and two species, F. sacchari and F. verticillioides were isolated from infected leaves of sugarcane (Table 1).

A fragment of $2.6 \mathrm{~kb}$ was amplified from all the isolates of Fusarium. After digestion using AluI, Eco88I, RsaI and $\mathrm{XhoI}$, estimated restriction fragment size and the restriction patterns $(\mathrm{A}-\mathrm{N})$ are summarized in table 2 . Two to six fragments ranging from 0.2 to $1.7 \mathrm{~kb}$ were produced, however fragments less than $100 \mathrm{bp}$ were not taken into consideration as the fragments were not clearly resolved. The total sizes of the restriction fragments did not always add up to the undigested $2.6 \mathrm{~kb}$ fragment which could be due to the difficulty in detecting very small or co-migrating fragments. Highly variable restriction patterns were observed among the isolates (Table 2). RsaI showed the highest variability with 14 patterns, followed by Eco88I with 11 patterns. Both $A l u \mathrm{I}$ and XhoI produced six patterns.

AluI patterns differentiate between isolates of $F$. $f u$ jikuroi and F. proliferatum from the other species of $F u$ sarium, while RsaI patterns differentiate Fusarium species section Liseola from F. oxysporum. IGS region of $F$. oxysporum, some isolates of F. proliferatum, and most of the $F$. verticillioides isolates did not have restriction sites for XhoI. All the four isolates of F. subglutinans, produced the same XhoI patterns. It was also noted that isolates of F. verticillioides from maize and sugarcane produced the same Eco881 and XhoI patterns whereas isolates from rice 
Table 1. Morphologically identified species of Fusarium from rice, sugarcane and maize from the field and stock culture used in RFLP-IGS analysis

\begin{tabular}{|c|c|c|}
\hline Isolate & Host & Species \\
\hline \multicolumn{3}{|c|}{ Fusarium isolates from the field } \\
\hline F3 & maize (flower) & F. oxysporum \\
\hline B7 & maize (kernel) & F. oxysporum \\
\hline B8 & maize (kernel) & F. oxysporum \\
\hline P3 & rice (root) & F. oxysporum \\
\hline JF5 & maize (kernel) & F. proliferatum \\
\hline P1 & rice & F. proliferatum \\
\hline P2 & rice & F. proliferatum \\
\hline $\mathrm{P} 4$ & rice & F. proliferatum \\
\hline $\mathrm{T} 5$ & sugarcane & F. sacchari \\
\hline T6 & sugarcane & F. sacchari \\
\hline $\mathrm{T} 7$ & sugarcane & F. sacchari \\
\hline $\mathrm{T} 8$ & sugarcane & F. sacchari \\
\hline P5 & rice & F. sacchari \\
\hline B10 & maize (kernel) & F. subglutinans \\
\hline F2 & maize (kernel) & F. subglutinans \\
\hline B1 & maize (kernel) & F. verticillioides \\
\hline B11 & maize (kernel) & F. verticillioides \\
\hline B3 & maize (kernel) & F. verticillioides \\
\hline B4 & maize (kernel) & F. verticillioides \\
\hline B5 & maize (kernel) & F. verticillioides \\
\hline B6 & maize (kernel) & F. verticillioides \\
\hline F1 & maize (kernel) & F. verticillioides \\
\hline JB1 & maize (kernel) & F. verticillioides \\
\hline JB2 & maize (kernel) & F. verticillioides \\
\hline JB3 & maize (kernel) & F. verticillioides \\
\hline JB4 & maize (kernel) & F. verticillioides \\
\hline JD4 & maize (kernel) & F. verticillioides \\
\hline B2 & maize (kernel) & F. verticillioides \\
\hline $\mathrm{T} 1$ & sugarcane & F. verticillioides \\
\hline $\mathrm{T} 2$ & sugarcane & F. verticillioides \\
\hline \multicolumn{3}{|c|}{ Fusarium isolates from the stock culture } \\
\hline 0621 & rice & F. fujikuroi \\
\hline 3132 & rice & F. fujikuroi \\
\hline 3074 & rice & F. proliferatum \\
\hline 3095 & rice & F. proliferatum \\
\hline 3262 & sugarcane & F. sacchari \\
\hline 3084 & rice & F. sacchari \\
\hline 3308 & sugarcane & F. subglutinans \\
\hline 3077 & rice & F. subglutinans \\
\hline 3061 & rice & F. verticillioides \\
\hline 3137 & rice & F. verticillioides \\
\hline
\end{tabular}

Table 2. Restriction patterns (A-N) and estimated restriction band sizes after digestion with four restriction enzymes

\begin{tabular}{|c|c|c|c|c|}
\hline \multirow{2}{*}{$\begin{array}{c}\text { Restriction } \\
\text { pattern }\end{array}$} & \multicolumn{4}{|c|}{ Restriction bands [bp] } \\
\cline { 2 - 5 } & AluI & Eco 88I & RsaI & XhoI \\
\hline A & $800,500,400,380,220,200$ & 1500,1100 & $900,600,400,380$ & 2600 \\
\hline B & $800,500,400,380,200$ & 1100,400 & $900,700,400,380$ & 1300 \\
\hline C & $800,500,400,380,300,200$ & 1100,250 & $900,750,500,400,380$ & 1700,950 \\
\hline D & $800,500,400,220,200$ & 1500,900 & $750,500,400,380$ & $1300,950,400$ \\
\hline E & $700,500,400,380,200$ & $1500,900,250$ & $900,750,400,380$ & 1300,950 \\
\hline F & $1000,300,280,220$ & 1300,900 & $1350,600,400$ & - \\
\hline G & - & $1300,1100,200$ & $700,500,400,380$ & - \\
\hline H & - & $1100,900,400,250,200$ & $800,700,400,350$ & - \\
\hline I & - & $1200,900,250,200$ & $600,500,400,380$ & - \\
\hline J & - & $1300,900,250,200$ & $600,500,400$ & - \\
\hline K & - & $1500,900,200$ & $700,600,550,400,380$ & - \\
\hline L & - & - & $700,600,550,400$ & - \\
\hline M & - & - & $700,600,550,400,250$ & - \\
\hline N & - & - & $900,600,550,400$ & \\
\hline
\end{tabular}


showed different Eco881 and XhoI patterns, from isolates of maize and sugarcane. Based on the restriction patterns, 25 haplotypes were identified among the 40 isolates (Table 3). Intraspecific and interspecific variations were observed within and between the six species of Fusarium. The two isolates of F. fujikuroi showed the same haplotypes which were different from isolates of F. proliferatum in which the isolates showed five haplotypes. Four haplotypes were found among the isolates of F. oxysporum and F. subglutinans. For isolates of F. verticillioides, five haplotypes were obtained in which isolates from rice showed slightly different haplotypes from isolates of maize and sugarcane.

As the Fusarium species showed variable restriction patterns, UPGMA cluster analysis was performed to clus- ter the isolates and to estimate the intraspecific and interspecific variability. In the dendrogram (Fig. 1), isolates of F. fujikuroi from rice were clustered together with isolates of $F$. proliferatum from rice and maize with similarity values of $88-100 \%$. Isolates of F. verticilliodes from maize and sugarcane were clustered in sub-sub-cluster A1b with similarity values ranging from $92-100 \%$. Sub-cluster A2 comprised isolates of $F$. oxysporum from maize and rice (P3). Isolates of F. subglutinans from rice and maize and isolates of $F$. sacchari from rice and sugarcane, were clustered together in sub-cluster B with similarity values of $77-100 \%$. Main Cluster II consisted of only two isolates of $F$. verticillioides from rice.

Table 3. Morphologically identified and RFLP-IGS haplotypes of Fusarium isolates from rice, sugarcane and maize

\begin{tabular}{|c|c|c|c|c|c|c|c|}
\hline Isolate & Host & Species & $A l u \mathrm{I}$ & Eco88I & $R s a \mathrm{I}$ & XhoI & $\begin{array}{c}\text { IGS } \\
\text { haplotype }\end{array}$ \\
\hline 0621 & rice & F. fujikuroi & $\mathrm{A}$ & $\mathrm{A}$ & $\mathrm{A}$ & $\mathrm{A}$ & 1 \\
\hline 3132 & rice & F. fujikuroi & $\mathrm{A}$ & $\mathrm{A}$ & $\mathrm{A}$ & $\mathrm{A}$ & 1 \\
\hline F3 & maize (flower) & F. oxysporum & A & $\mathrm{E}$ & $\mathrm{L}$ & $\mathrm{A}$ & 2 \\
\hline B7 & maize (kernel) & F. oxysporum & $\mathrm{C}$ & $\mathrm{K}$ & $\mathrm{K}$ & $\mathrm{A}$ & 3 \\
\hline B8 & maize (kernel) & F. oxysporum & $\mathrm{D}$ & $\mathrm{K}$ & $\mathrm{M}$ & $\mathrm{A}$ & 4 \\
\hline P3 & rice & F. oxysporum & $\mathrm{B}$ & $\mathrm{D}$ & $\mathrm{L}$ & $\mathrm{A}$ & 5 \\
\hline JF5 & maize (kernel) & F. proliferatum & $\mathrm{B}$ & $\mathrm{A}$ & $\mathrm{A}$ & $\mathrm{F}$ & 6 \\
\hline 3074 & rice & F. proliferatum & B & A & A & A & 7 \\
\hline 3095 & rice & F. proliferatum & $\mathrm{B}$ & $\mathrm{A}$ & $\mathrm{F}$ & $\mathrm{A}$ & 8 \\
\hline P1 & rice & F. proliferatum & $\mathrm{B}$ & $\mathrm{A}$ & $\mathrm{B}$ & $\mathrm{A}$ & 9 \\
\hline $\mathrm{P} 2$ & rice & F. proliferatum & $\mathrm{B}$ & $\mathrm{A}$ & $\mathrm{B}$ & $\mathrm{A}$ & 9 \\
\hline $\mathrm{P} 4$ & rice & F. proliferatum & $\mathrm{B}$ & $\mathrm{A}$ & $\mathrm{N}$ & $\mathrm{A}$ & 10 \\
\hline $\mathrm{T} 6$ & sugarcane & F. sacchari & B & $\mathrm{K}$ & $\mathrm{I}$ & $\mathrm{C}$ & 11 \\
\hline $\mathrm{T} 7$ & sugarcane & F. sacchari & $\mathrm{B}$ & $\mathrm{J}$ & $\mathrm{I}$ & $\mathrm{D}$ & 12 \\
\hline $\mathrm{T} 8$ & sugarcane & F. sacchari & $\mathrm{B}$ & $\mathrm{J}$ & $\mathrm{I}$ & $\mathrm{D}$ & 12 \\
\hline 3262 & sugarcane & F. sacchari & E & $\mathrm{J}$ & G & $\mathrm{D}$ & 13 \\
\hline $\mathrm{T} 5$ & sugarcane & F. sacchari & E & $\mathrm{C}$ & $\mathrm{B}$ & $\mathrm{D}$ & 14 \\
\hline 3084 & rice & F. sacchari & E & $\mathrm{I}$ & $\mathrm{D}$ & $\mathrm{D}$ & 15 \\
\hline P5 & rice & F. sacchari & E & $\mathrm{F}$ & $\mathrm{J}$ & $E$ & 16 \\
\hline B10 & maize (kernel) & F. subglutinans & $\mathrm{B}$ & $\mathrm{F}$ & $\mathrm{I}$ & $\mathrm{D}$ & 17 \\
\hline $\mathrm{F} 2$ & maize (kernel) & F. subglutinans & $E$ & $\mathrm{~J}$ & G & $\mathrm{D}$ & 18 \\
\hline 3308 & sugarcane & F. subglutinans & $\mathrm{B}$ & $\mathrm{J}$ & $\mathrm{I}$ & $\mathrm{D}$ & 19 \\
\hline 3077 & rice & F. subglutinans & E & $\mathrm{H}$ & $\mathrm{C}$ & $\mathrm{D}$ & 20 \\
\hline 3061 & rice & F. verticillioides & $B$ & G & $\mathrm{H}$ & $B$ & 21 \\
\hline 3137 & rice & F. verticillioides & $\mathrm{F}$ & G & $\mathrm{H}$ & $\mathrm{B}$ & 22 \\
\hline B1 & maize (kernel) & F. verticillioides & $E$ & $\mathrm{~B}$ & $\mathrm{E}$ & $\mathrm{A}$ & 23 \\
\hline B11 & maize (kernel) & F. verticillioides & $\mathrm{E}$ & $\mathrm{B}$ & E & $\mathrm{A}$ & 23 \\
\hline B3 & maize (kernel) & F. verticillioides & E & B & $\mathrm{E}$ & A & 23 \\
\hline B4 & maize (kernel) & F. verticillioides & E & $\mathrm{B}$ & $\mathrm{E}$ & $\mathrm{A}$ & 23 \\
\hline B5 & maize (kernel) & F. verticillioides & $E$ & $\mathrm{~B}$ & $E$ & $\mathrm{~A}$ & 23 \\
\hline B6 & maize (kernel) & F. verticillioides & $E$ & B & $\mathrm{E}$ & $\mathrm{A}$ & 23 \\
\hline $\mathrm{T} 1$ & sugarcane & F. verticillioides & E & $\mathrm{B}$ & $\mathrm{E}$ & $\mathrm{A}$ & 23 \\
\hline F1 & maize (kernel) & F. verticillioides & E & $\mathrm{B}$ & B & $\mathrm{A}$ & 24 \\
\hline JB1 & maize (kernel) & F. verticillioides & E & B & B & $\mathrm{A}$ & 24 \\
\hline JB2 & maize (kernel) & F. verticillioides & $E$ & $\mathrm{~B}$ & $\mathrm{~B}$ & $\mathrm{~A}$ & 24 \\
\hline JB3 & maize (kernel) & F. verticillioides & E & B & $\mathrm{B}$ & $\mathrm{A}$ & 24 \\
\hline JB4 & maize (kernel) & F. verticillioides & E & $\mathrm{B}$ & $\mathrm{B}$ & $\mathrm{A}$ & 24 \\
\hline JD4 & maize (kernel) & F. verticillioides & $E$ & $\mathrm{~B}$ & $\mathrm{~B}$ & $\mathrm{~A}$ & 24 \\
\hline $\mathrm{T} 2$ & sugarcane & F. verticillioides & $E$ & $\mathrm{~B}$ & $B$ & $\mathrm{~A}$ & 24 \\
\hline B2 & maize (kernel) & F. verticillioides & $\mathrm{F}$ & $\mathrm{B}$ & $\mathrm{E}$ & $\mathrm{A}$ & 25 \\
\hline
\end{tabular}




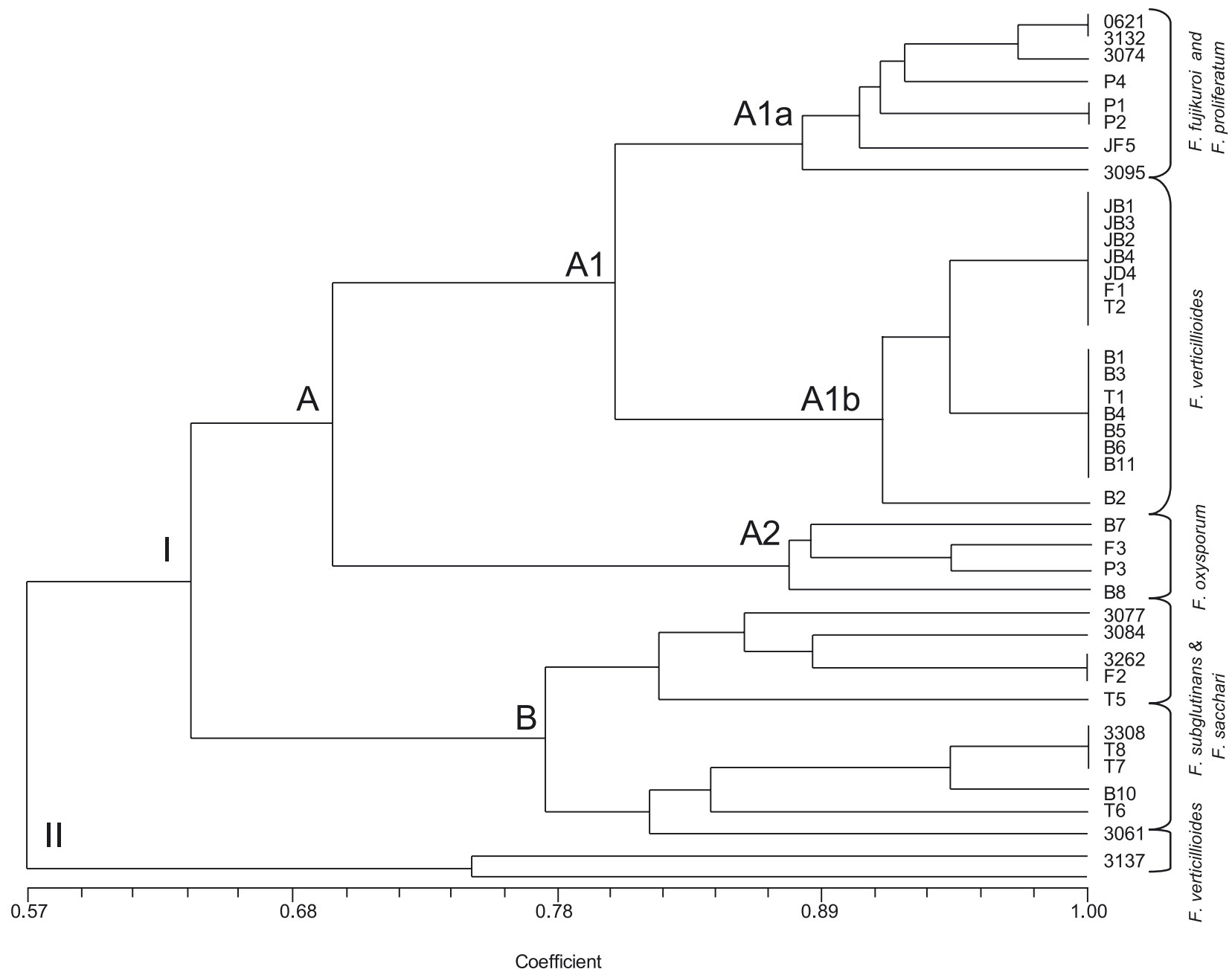

Fig. 1. Dendogram generated by UPGMA cluster analysis of restriction bands of IGS region using AluI, Eco88I, RsaI and XhoI showing relationships among 40 isolates of Fusarium from rice, sugarcane and maize

\section{DISCUSSION}

Although, some species of Fusarium were difficult to identify morphologically, identification based on morphological characteristics is necessary, as it allows the sorting of Fusarium isolates before applying other methods of identification and characterization (Leslie and Summerell 2006).

Morphological characteristics of $F$. proliferatum were similar with F. verticillioides. The primary characters used to differentiate the two species was their form of microconidia chains. F. proliferatum formed microconidia in a chain from polyphialides and the chain was shorter than F. verticillioides (Burgess et al. 1988; Leslie and Summerell 2006). F. verticillioides produced a long chain of microconidia by the monophialides.

Morphological characteristics of F. subglutinans and F. sacchari were also very similar, and to differentiate both species was difficult. However, based on XhoI patterns, isolates of $F$. subglutinans from different hosts produced the same patterns which were different from XhoI patterns of F. sacchari.

F. verticillioides, F. sacchari, F. proliferatum, F. fujikuroi and F. subglutinans are members of the Gibberella fujikuroi species complex, which are morphologically simi- lar and phylogenetically closely related (Nirenberg and O'Donnell 1998; O'Donnell et al. 1998). Therefore, after identification using morphological characteristics, the isolates were characterized using restriction analysis of IGS region. The region is useful for early characterization of Fusarium species as IGS region was reported to be the most evolving spacer region (Hills and Dixon 1991), due to its larger size and lack of selective constrain. Thus, IGS region is suitable for studying relationships at intraspecies levels and among closely related species (Appel and Gordon 1995).

Variable restriction patterns were obtained from RFLP of IGS region. Variations in IGS region could be due to minor changes in the nucleotide composition which may generate different restriction patterns even within the same species (Konstantinova and Yli-Mattila 2004). Variations could also be caused by length and sequence variations especially among closely related species (Martin 1990; Hillis and Dixon 1991). RFLP-IGS of several species of Fusarium have also revealed variable restriction patterns such as variability among 22 strains of F. oxysporum (Kim et al. 2001), 33 isolates of F. verticillioides (Patinõ et al. 2006) and among 27 isolates of F. equiseti (Kosiak et al. 2005). 
From the dendrogram generated using UPGMA cluster analysis, isolates of $F$. oxysporum (section Elegans) from rice and maize were grouped in main cluster I which also grouped isolates of F. fujikuroi, F. proliferatum and F. verticillioides. The results suggest that $F$. oxysporum was related to the species in the section Liseola which is not unexpected as species in the section Liseola are known to be related to species in section Elegans. Guadet et al. (1989) reported that based on sequence analysis part of $28 \mathrm{~S}$ rRNA, several species of Fusarium in section Elegans were closely related to species of Fusarium in the section Liseola.

F. proliferatum and F. fujikuroi from rice were clustered together in sub-cluster A1a which is not surprising as both species are regarded as sibling species (Leslie and Summerell 2006) and often associated with bakanae disease of rice.

F. subglutinans and F. sacchari were also clustered together. F. sacchari was recognized as a species by Gerlach and Nirenberg (1982) but Nelson et al. (1983) regarded the species to be synonomous with F. subglutinans. F. subglutinans was commonly found on several host plants such as maize, sugarcane and mango (Booth 1971) and has been associated with disease on sugarcane (Muramoto et al. 1993) and maize (Munkvold 2003; Gortz et al. 2008).

Isolates of $F$. verticillioides were clustered in two clusters in which sub-cluster A1b comprised isolates from maize and sugarcane, and isolates from rice were clustered in the main cluster II. The separate grouping of F. verticillioides isolates could be due to different levels of fumonisin production. In a study by Steenkamp et al. (2000), F. verticillioides isolates formed two distinct clusters, one cluster corresponding to fumonision producing isolates from cereals and the other cluster corresponding to non-fumonisin producing isolates from banana. In conclusion, six species of Fusarium were isolated from rice root, different parts of maize plant and sugarcane leaves. Although highly variable restriction patterns were produced, the technique is useful for early characterization of Fusarium species, as it could be used to complement morphological characterization.

\section{REFERENCES}

Appel D.J., Gordon T.R. 1995. Intraspecific variation within populations of Fusarium oxysporum based on RFLP analysis of the intergenic spacer region of the rDNA. Exp. Mycol. 19 (2): 120-128.

Booth C. 1971. The Genus Fusarium. Commonwealth Agricultural Bureau, Bucks, United Kingdom.

Burgess L.W., Liddell C.M., Summerell B.A. 1988. Laboratory Manual for Fusarium. Research. Department of Plant Pathology and Agricultural Entomology, University of Sydney.

Edel V., Steinberg C., Avelange I., Langueere G., Alabouvette C. 1995. Comparison of three molecular methods for the identification of Fusarium oxysporum strains. Phytopathology 85 (5): 579-585.

Gerlach W., Nirenberg H. 1982. The genus Fusarium: A pictorial atlas. Mitt. Biol. Bundesanst. Land- u. forstwirtsch. Berl.Dahlem 209: 1-405
Gortz A., Oerke E.C., Steiner U., Wallwijk C., de Vriees I., Dehne H.W. 2008. Biodiversity of Fusarium species causing ear rot in Germany. p. 617-621. In: Proc. 3rd International Fusarium Head Blight Symposium Suppl. B. 51. Szeged, Hungary.

Guadet J., Julien J., Lafay J.F., Brygod Y. 1989. Phylogeny of some Fusarium species, as determined by large - subunit rRNA sequence comparison. Mol. Biol. Evol. 6 (3): 227-242.

Hillis D.M., Dixon M.T. 1991. Ribosomal DNA: Molecular evolution and phylogenetic inference. Q. Rev. Biol. 66 (4): 411-453.

Kim H.J., Choi Y.K., Min B.R. 2001. Variation of the Intergenic Spacer (IGS) region of ribosomal DNA among Fusarium oxysporum formae speciales. J. Microbiol. 39 (4): 265-272.

Kosiak E.B., Holst-Jensen A., Rundberget T., Jaen M.T.G., Torp M. 2005. Morphological, chemical and molecular differentiation of Fusarium equiseti isolates from Norwegian cereals. Int. J. Food Microbiol. 99 (2): 195-206.

Konstantinova P., Yli-Mattila T. 2004. IGS-RFLP analysis and dea velopment of molecular markers for identification of Fusarium poae, Fusarium langethiae, Fusarium sporotrichioides and Fusarium kyushuense. Int. J. Food Microbiol. 95: 321-331.

Leslie J.F., Summerell B.A. 2006. The Fusarium Laboratory Manual. 1st ed. Blackwell.

Marasas W.F.O., Kriek N.P.J., Wiggins V.M., Steyn I.S., Towers D.L., Hastie T.J. 1979. Incidence, geographical distribution and toxigenicity of Fusarium species in South African corn. Phytopathology 69: 1181-1185.

Martin F.N. 1990. Variation in ribosomal DNA repeat unit within single oospore isolates of the genus Pythium. Genome 33 (4): 585-591.

Munkvold G.P. 2003. Epidemiology of Fusarium diseases and their mycotoxin in maize ears. Eur. J. Plant Pathol. 109 (7): 705-713.

Muramoto M., Tashiro T., Minarnihasni H. 1993. Distribution of Fusarium moniliforme var. subglutinans in Kagoshima Prefecture and its pathogenicity. J. Japanese Forest. Soc. 75 (1): $1-9$.

Nelson A.J., Eliss K.S., Avevalo G.E., Darlington L.C., Bailey B.A. 1997. Genetic characterization by RAPD analysis of isolates of Fusarium oxysporum f. sp. erythroxyli associated with an emerging epidermic in Peru. Phytopathology 87 (12): 1220-1225.

Nelson P.E., Toussoun T.A., Cook R.J. 1983. Fusarium Species. An Illustrated Manual for Identification. The Pennsylvania State University Press. University Park and London.

Nirenberg H.I., O'Donnell K. 1998. New Fusarium species and combinations within the Gibberella fujikuroi species complex. Mycologia 90 (3): 434-458.

O'Donnell K., Ciglenik E., Nirenberg H.I. 1998. Molecular systematics and phylogeography of the Gibberella fujikuroi species complex. Mycologia 90: 465-493.

O’Donnell K., Gherbawy Y., Schweighkofler W., Adler A., Prillinger H. 1999. Phylogenetic analyses of DNA sequence and RAPD data compared in Fusarium oxysporum and related species from maize. J. Phytopathol. 147 (7-8): 445-452.

Patiño B., Mirete S., Vázquez C., Jiménez M., Rodríguez M.T., González-Jaén M.T. 2006. Characterization of Fusarium verticillioides strains by PCR-RFLP analysis of the intergenic spacer region of the rDNA. J. Sci. Food Agric. 86 (3): 429-435. 
Rohlf F.J. 2000. NTSYSpc Numerical Taxonomy and Multivariate Analysis System Version 2.1. Exeter, New York.

Steenkamp E.T., Wingfield B.D., Desjardins A.E., Marasas W.F.O, Wingfield M.J. 2000. Cryptic speciation of Fusarium subglutinans. Mycologia 94 (6): 1032-1043.

Stephens C.T., de Vries R.H., Sink K.C. 1989. Evaluation of asparagus species for resistance to Fusarium oxysporum f. sp. asparagi and Fusarium moniliforme. Am. Soc. Hort. Sci. 24 (2): 365-368.

\section{POLISH SUMMARY}

\section{CHARAKTERYSTYKA IZOLATÓW FUSARIUM Z RYŻU, TRZCINY CUKROWEJ I KUKURYDZY PRZY WYKORZYSTANIU RFLP-IGS}

Izolaty Fusarium z ryżu, trzciny cukrowej i kukurydzy, określono jako F. verticillioides, F. sacchari, F. proliferatum, F. subglutinans, F. fujikuroi oraz F. oxysporum. Gatunki te scharakteryzowano przy pomocy analizy restrykcyjnej międzygenowego niekodującego odcinka genu (RLFP-
-IGS), wykorzystując AluI, Eco881, RsaI i Hoi. Określono dwadzieścia pięć haplotypów wśród izolatów Fusarium, co wskazywało na wysoki poziom zmienności. Przeprowadzono analizę skupień w celu pogrupowania izolatów i określenia intraspecyficznej interspocyficznej zmienności. Izolaty F. fujikuroi z ryżu zgrupowano razem z izolatami F. proliferatum z ryżu i kukurydzy wykazującymi podobieństwo $88-100 \%$. Izolaty F. verticillioides z kukurydzy i trzciny cukrowej zgrupowano w ramach wartości podobieństwa od 92 do $100 \%$, a dwa izolaty z ryżu tworzyły inne zgrupowanie. Izolaty F. oxysporum z kukurydzy i ryżu zgrupowano również razem, z wartością podobieństwa od 87 do $95 \%$. Izolaty F. subglutinans z ryżu i kukurydzy i $F$. sacchari z ryżu i trzciny cukrowej zostały też zgrupowane razem i miały wartość podobieństwa $77-100 \%$. W oparciu o analizę RLFP-IGS obserwowano zmienność $\mathrm{w}$ ramach i pomiędzy gatunkami Fusarium z ryżu, kukurydzy i trzciny cukrowej. Technika RLFPIGS mogłaby być wykorzystywana w celu uzupełnienia charakterystyki mikroskopowej i do określenia genetycznych związków pomiędzy gatunkami. 